\title{
Constitutional Principle of Equality in the Legal Systems of the BRICS States
}

\author{
Mezyaev A. \\ University of Management TISBI \\ Kazan, Russia \\ motrokhin@mail.ru
}

\author{
Motrokhin E. \\ Associate Professor, University of Management TISBI \\ Kazan, Russia \\ motrokhin@mail.ru
}

\author{
Matveev G. \\ Associate Professor, University of Management TISBI \\ Kazan, Russia \\ motrokhin@mail.ru
}

\begin{abstract}
The article explores the principle of equality, one of the most established and widespread in the constitutional law in the BRICS countries, the practice of its consolidation, implementation, as well as the existing problems in this area. It is shown that the implementation of this principle should be associated with increased protection of some "vulnerable" groups of the population: national minorities, women, children, persons with disabilities and others. The provisions of constitutions and legislation of such countries as the Russian Federation, China, India, the Federal Republic of Brazil and South Africa are analyzed. It is concluded that in many cases the formal Declaration of the citizens' equality principle does not always correspond to the actual practice of social relations in such areas as the use of national languages, inter-ethnic relations, gender equality and so on. In this regard, measures are proposed to improve the legislative regulation of the relations in the BRICS countries question.
\end{abstract}

Keywords-equality of people; BRICS; human rights; constitution; discrimination; national minorities; women.

\section{INTRODUCTION}

The problems of people equality have been exciting for centuries. Perhaps the first constitutional act, which reflected the principle of equality was the Declaration of Human and Citizen Rights in 1789. Subsequently, this principle was enshrined in the constitutions of the vast majority of countries, as well as in the most authoritative international acts, for example in the preamble and art. 1 of the UN Charter of 1945 and in the Universal Declaration of Human Rights of 1948. Art. 1 of the Declaration of Human and Citizen Rights says: "People are born and remain free and equal in rights". However, as the famous French lawyer François Luchaire wrote, "they are never such in reality" [7, P. 191]. In other words, it is necessary to differentiate the concepts of "equality" and "equality." The constitution and legislation can provide individuals with an equal amount of fundamental rights and freedoms, create the same legal (but not actual) opportunities to use them, and establish equal responsibilities. However, for different groups of the population, these rights and freedoms may vary; important here is to avoid discrimination within each such group [2, P. 30].

Problems associated with discrimination of various social groups remain relevant for many countries, which is confirmed, in particular, by the data provided in the report of the Human Rights Council (HRC) of the UN General Assembly 73rd session (facts of discrimination based on national, religious, linguistic grounds in a number of countries; the need to protect against all types of discrimination against persons with disabilities, including ensuring their right to access to justice; continuing discrimination against women and girls, including increased gender segregation in the labor market, etc.)

Much attention is paid to issues of equality, the fight against different types of discrimination in the BRICS countries. Ultimately, this should contribute to the growth of economic attractiveness of the BRICS member states, opening up great opportunities for their socio-economic development. This article discusses the constitutional and legal regulation and some problematic issues of the equality principle in individual BRICS countries.

\section{RESULTS}

\section{Russian Federation}

Article 19 of the Russian Constitution enshrines three aspects of the equality principle. First, part 1 states that everyone is equal before the law and the courts, which is consistent with art. 7 of the Universal Declaration of Human Rights, which proclaims the equality of all persons before the law and their right, without distinction, to equal protection of the law. Secondly, in part 2 it is said that the state guarantees equality of human and civil rights and freedoms regardless of 
sex, race, nationality, language, origin, property and official status, place of residence, attitude to religion, beliefs, membership of public associations, as well as other circumstances. Finally, in part 3 of art. 19 the Constitution formulates the traditional requirement for Russian constitutionalism of equality of men and women, which is strengthened in comparison with the previously existing Russian Constitution by mentioning not only equal rights and freedoms, but also equal opportunities for their implementation [3]. These constitutional provisions are further developed in many legislative acts. Thus, in art. 64 of the Labour Code of the Russian Federation states that "any direct or indirect restriction of rights or establishment of direct or indirect advantages at the conclusion of an employment contract, depending on sex, race, skin color, nationality, language, origin, property, family, social and official status, age, place of residence (including the presence or absence of registration at the place of residence or stay), attitude to religion, beliefs, membership or non-membership in public associations or any social groups, as well as other circumstances, not connected with business qualities of workers, it is not allowed, except for cases in which the right or the duty to establish such restrictions or advantages are provided by Federal laws". We should also note Federal law №181-FZ of 24.11.1995 "On social protection of disabled persons in the Russian Federation", art. 3.1 of which prohibits discrimination on the basis of disability and, moreover, defines such discrimination. Thus, the normative development of the principle of equality in the Russian legal system gets through the progressive establishment of measures that protect against discrimination of certain social groups and categories of individuals' representatives (as one of the latest examples call additional guarantees of citizens social support approaching retirement age stipulated by the Federal law from 03.10.2018, №350-FZ).

At the same time, sometimes there is criticism of the practice of implementing the constitutional principle of equality in certain areas, as is the case in the field of teaching in the national (state) languages of individual subjects of the Russian Federation. For example, in the Republic of Tatarstan, certain figures of science and culture noted the insufficient and low level of teaching the Tatar language both in secondary schools and in higher education, despite the fact that Universities with training in the Tatar language in many areas in the Republic are practically absent. Indeed, by virtue of part 2 of art. 26 of the Constitution, everyone has the right to use his native language, freely choose the language of communication, upbringing, education and creativity. At the same time, the Federal law of 29.12.2012 №273-FZ "On education in the Russian Federation" in part 2 of art. 14 establishes that educational activities in educational institutions are carried out in the state language of the Russian Federation, unless otherwise established by this article. And part 4 of this article, citizens of the Russian Federation have the right to receive preschool, primary General and basic General education in their native language among the languages of the peoples of the Russian Federation (higher education is not included here). We add to this that the Federal law of 22.08.1996 №125-FZ "On higher and postgraduate professional education" does not contain provisions on the right to receive higher education in their native language. It seems that filling this gap in the current legislation is an urgent task.

\section{People's Republic of China}

Problems of equality, elimination of discrimination are relevant for China, due to factors such as a sharp property stratification in society, exacerbated by the global economic recession; multi-ethnic composition of the population, and the resulting problems of the national minorities rights (eg, Uighurs); gender inequality, etc.in the Constitution of the PRC in 1982, equality issues are given considerable attention, starting with art. 4, which enshrines the equality of all nationalities. It states, inter alia, that the state guarantees the legitimate rights and interests of all national minorities and protects and promotes equality, cohesion and mutual assistance among all nationalities. Every nationality has the freedom to use and develop its language and script. However, in reality, all ethnic and religious conflicts (in particular, those related to discrimination and assimilation of Uighurs in the Xinjiang Uighur Autonomous region) are yet not finally resolved in the country. Because of the oppression of Muslims in China, even international pressure was exerted, but so far to no avail.

Under art. 48 of the PRC Constitution, women are granted equal rights with men in all spheres of life - political, economic, cultural, social and family. The state protects the rights and interests of women, applies the principle of equal pay for equal work for men and women. At the same time, after the reform of the political and economic systems of China in the 80 s of the XX century, the issue of women's employment became acute. In this situation, men used the advantages that they received from the existence of a planned economy, as a result of which a large number of women lost their jobs [1]. Women in China are poorly represented in politics, they do not fully exercise their right to vote, and they hardly take part in political debates. Thus, in the 17th Central Committee of the Communist party of China, a total of 204 people were elected, of whom only 13 were women, which was $5 \%$. Thus, for the effective implementation of the constitutional principle of equality, the authorities of this country will have to implement a number of measures, both legislative (elimination of disparities between different national and social groups) and organizational.

\section{Republic of India}

India's modern development, like that of China, is closely linked to globalization and persistent inequalities in some areas of public life. The fight against inequality has particularly affected the legal status of women and some disadvantaged social groups. Here the major milestones were the most important "key" laws, which reflected the priority directions of rule-making aimed at granting the full amount of rights and freedoms to every citizen of the Republic of India. 
The Constitution of India of 1950 enshrined many formal guarantees of equality for all Indians: in art. 14 speaks of equality of all before the law, including the right to equal protection of the laws; art. 15 prohibits discrimination on grounds of religion, race, caste, sex or place of birth; art. 16 is about equality of opportunity in employment in state institutions or enterprises; art. 17 enshrines the abolition of the practice of "untouchability" and art. 18 - abolition of titles. In accordance with these provisions, the country made significant progress towards the establishment of the equality principle. Thus, the institution of untouchability is prohibited and guarantees are provided to all castes with respect to access to temples, places of public catering, etc. Provision is also made for the allocation of a certain number of seats for certain castes and scheduled tribes in the legislative bodies of the country and States. The Untouchability act 1955 condemned all forms of untouchability. In addition, various educational programmes are being implemented in India, which also helps to combat inequality. The literacy rate has reached $65 \%$.

However, despite the achievements, it should be noted that until recently, India has not been overcome and some of the problems associated with, for example, the unequal position of women in public life, the preservation of ancient customs, which are often discriminatory (the custom of sati the death of a widow after the deceased spouse) [8,9]. For modern India as a whole is characterized by the modernization of traditional legal culture, which is associated with increased attention of the state to the issues of systematization and reform of the extremely complicated, burdened with a mass of existing customs, esoteric norms and largely religious marriage and family law, which is the most important, socially constitutive branch of the country.

\section{Federal Republic of Brazil}

The current Constitution of Brazil was adopted in 1988 and is the eighth in the history of the country. The principle of equality is contained in art. 5 of part II, Chapter I, which reads as follows: "all are equal before the law without distinction of any kind, Brazilians and foreigners residing in the country are guaranteed the inviolability of the right to life, liberty, equality, security and property", while "men and women are equal in rights and duties in the manner prescribed by this Constitution...". Another aspect of the constitutional principle of equality we find in art. 7 of Chapter II, which mentions, among other social rights of workers, inter alia: prohibition of differences in wages, performance and criteria for employment on the basis of sex, age, colour or civil status; prohibition of any discrimination in respect of wages and employment of workers with physical disabilities; prohibition of differences between physical, technical and mental work or between persons in the relevant professions; equality of rights between employees who are in a permanent working relationship, and employees operating outside the enterprise. Some provisions of art. 7 can be assessed as somewhat declarative. For example, how can the "prohibition of distinctions between physical, technical and mental work" be understood and applied in practice, whereas in the same article there is a requirement that the level of wages correspond to the "quantity and complexity of work" - the Constitution does not contain an answer to this question.

Discrimination against blacks and indigenous peoples is one of the major problems facing Brazil today (along with persistent socio-economic inequality). In his report dated 07.05.2012 submitted to UN HRC, Brazil said the main role of the constitutional principle of equality and that racism was declared a crime within the meaning of articles 3, 5 and 7 of the Constitution of 1988, the country has a national Commissioner for the promotion of racial equality and the national Council on the same issues. And after 2010 Brazil had adopted a National strategy for the promotion of racial equality by adopting a Law on racial equality. Nevertheless, the issues of overcoming racial and ethnic inequality, as well as discrimination against women, are still relevant in this country.

\section{Republic of South Africa}

The issues of legal equality in general and its legal regulation, in particular, in the Republic of South Africa are of particular importance, and special attention is given to it. This, of course, is easily explained by the historical conditions in which South African society developed over several hundred years until the end of the twentieth century.

Only in 1994 the first democratic elections took place in the country and the apartheid system, which was built on the legislative consolidation of inequality of people, was eliminated. And although the basis of the system was based on racial differences, the new democratic constitution of the country proclaimed the principle of equality in a much broader sense. This circumstance should be taken into account especially when interacting with any bodies of a given state, issues of equality are for the state and all citizens, since this affects absolutely every person in South African society in the most serious way.

The final provisions of the Interim South African Constitution of 1993 explains the notion of «equality» as one of fundamental ideals that epitomized South Africa's program of transformation. Article 9 of the permanent South African constitution of 1996 establishes the general principle (« Everyone is equal before the law and has the right to equal protection and benefit of the law») and provides the more detailed clarifications that includes inter alia the following:

-that the meaning of equality includes but not limited to the «the full and equal enjoyment of all rights and freedoms»;

-that legislative and any other «measures designed to protect or advance persons, or categories of persons, disadvantaged by unfair discrimination may be taken»;

-that the state may not unfairly discriminate (either directly or indirectly) against anyone on the base of age, race or ethnic origin, gender, sex or sexual orientation, cultural affiliation or religion (the list is not exhaustive). There are also 
quite rare grounds enumerated in the text of the constitution, which for example includes disability or birth.

It should also be noted the adoption of a number of specialized regulations governing legal equality. Among them, the Promotion of Equality and Prevention of Unfair Discrimination Act, adopted in 2000.

\section{CONCLUSION}

BRICS is the informal organization of five states - Russian Federation, People's Republic of China, India, Brazil, and Republic of South Africa. This association is not an international organization in the international legal sense $[5, \mathrm{P}$. 381], but attention should be paid to the significant potential of its member states. The integration of these states will allow them to influence global processes in a new format [6, P. 544535], which will allow shifting the center of influence from the West to developing countries. Creation of the BRICS association specialized bodies, such as, for example, the New Development Bank. Given some trends in the development of international justice [4, P. 46-49], we can assume the creation of some bodies with judicial (arbitration) functions. All this necessitates legal studies of this association, including in matters of human rights fundamental principles regulation [5, P. 278-282] and legal systems in general.

\section{References}

[1] WAN Lee. A study of women's political participation in China's development. Daqing pedagogical journal. 2008, 4, pp. 42-43.

[2] Strashun B.A. Constitutional (state) law of foreign countries: textbook. Moscow: Prospect. 2013, 296.

[3] Topornin B.N., Baturin Y.M., Orekhov R.G. Russian Constitution. Commentary. M.: Legal literature. 1994, 624.

[4] Bassiouni M. S., Belyi I. J., Bogush G. I., Wan S., Vedernikova O. N., Veliyeva S. D., Wehrle G., Wilkicki P., Volevodz A. G., Volevodz V. A., Glotova S. V., Gritsaev S. A., Dodonov V. N., Doria J., Dremina-Volok N.V., Zaul V., Zelinskaya N. A., Ilutchenko N.V., Inogamova-Khegai L.V., Kayumova A. R. International criminal justice: contemporary issues. M.: Institute of law and public policy. 2009.

[5] Kurdyukov G. I., Abdullin A. I., Biryukov P. N., Davletgildeev R. S., Valeev R. M., Kayumova A. R., Marochkin S. Yu., Mezyaev A. B., Mingazov L. Kh., Motrokhin E. Y., Nugaeva N. G. International law: Textbook for bachelors. M.: Statute. 2017.

[6] Marochkin S. Yu., Mezyaev A. B., Kayumova A. R., Biryukov P. N. International law. General part: Textbook for students of higher educational institutions, studying in the direction and specialty "Jurisprudence". M. 2011.

[7] Luchaire F. Constitutional protection of the rights and freedoms of the individual: translation from French. M.: Publishing group "Progress" "Universe". 1993, 384.

[8] Alexsandr S. Kuznetsov. Russian Professor's meeting. Russian Journal of Physical Education and Sport. 2019, 14(1), pp. 17-22. DOI: 10.14526/2070-4798-2019-14-1-18-24

[9] Shinkarenko K.I. The Struggle of Indian reformers to improve the social and legal status of women in colonial India // Bulletin of the Moscow University. Series 11 "Law". 2009, 5, pp. 77-88. 